\title{
Obituary
}

\section{Professor Anita Harding}

Anita Harding died from cancer of the colon on 11 September 1995. Many readers of this Journal will have known her and her work. By her untimely death the field of clinical neurogenetics has lost an outstanding person at the height of her powers.

Anita was born and brought up in Birmingham, and was educated at King Edward VIth High School for Girls. She qualified in medicine at the Royal Free Hospital School of Medicine, where her future husband P K Thomas ("PK"), shown with Anita in the portrait, was Professor of Neurology. I was myself in PK's department at that time, and I remember Anita as a student already showing those features that were so evident in her later career: unbounded enthusiasm for neurology, exceptional powers of clinical observation, and a great sense of fun (exemplified then by an accurately observed caricature of the writer at a student Christmas Concert in 1974).

Her postgraduate clinical training in neurology was principally at the National Hospital for Nervous Diseases, Queen Square, while her research career began in the MRC Clinical Genetics Unit at the neighbouring Institute of Child Health. This juxtaposition proved to be extraordinarily fruitful because the National Hospital had access to many families with inherited neurological disorders. Seminal papers from that time defined the clinical phenotypes of the inherited ataxias - an area in which she was soon to become an international authority - and, jointly authored with $\mathrm{PK}$, delineated similarly the hereditary motor-sensory neuropathies. There followed a succession of key papers characterising the hereditary paraplegias, $\mathrm{X}$ linked recessive bulbospinal neuropathy, and multisystem disorder with cerebellar involvement. Ten years ago in a seminal paper published in Nature, she collaborated with Ian Holt and John Morgan-Hughes in

- the first description of mitochondrial DNA deletions in patients with mitochondrial myopathies, an area of research that continued to occupy her, together with the inherited ataxias, until the time of her death. Her highly regarded monograph The hereditary ataxias and related disorders is a testimony to her exceptional contributions to that field.

She founded the Clinical Neurogenetics group at Queen Square, the focus for a number of young clinical neurologists and neuroscientists wishing to learn the new molecular biological techniques and clinical genetic advances of her discipline. She was an excellent teacher and will be missed as much by her students as by her peers.

Her commitment to "Queen Square" was paramount. Her appointment to a Personal Chair at the Institute of Neurology in 1990 fittingly acknowledged her achievements and was welcomed by the clinical neuroscience community. She was poised to take over as Professor of Clinical Neurology at the Institute. She would have been an extremely strong candidate for established chairs at other universities had she chosen to apply, but she always made it clear where her primary allegiance lay and where she wished to continue to work.

Internationally she was known not only for her many contributions to scientific meetings and, at many in- stitutions, as visiting professor, but also for the important part she played - with Gérard Said and PK - in setting up and sustaining the European Neurological Society. She was on a number of editorial boards (including, of course, this journal's) and science committees (for example, the Wellcome Trust Neurosciences Grants Committee and the Muscular Dystrophy Group Medical Research Committee). She was due to serve on the Neurosciences Board of the Medical Research Council in October 1995.

Her final illness was short. All seemed well following initial surgery and treatment in the early part of 1995, but in August a further operation showed disseminated tumour. Those who were able to visit her during her last few days will remember the courage with which she faced the medical facts. She was being cared for at Bart's, and remarked to us poignantly after her second operation: "as a doctor, you know at once when you move from active to palliative care; they stop doing tests". Though having only a few days to live, characteristically she was interested in others and in their future plans, discussing with her doctoral students their research and their futures. She was always tremendously good company (her friends will remember highly convivial evenings continuing into the early hours even when she had a platform presentation to give only a few hours away); she remained so to the end. No loss in the clinical neuroscience community could be more greatly mourned.

JOHN NEWSOM-DAVIS

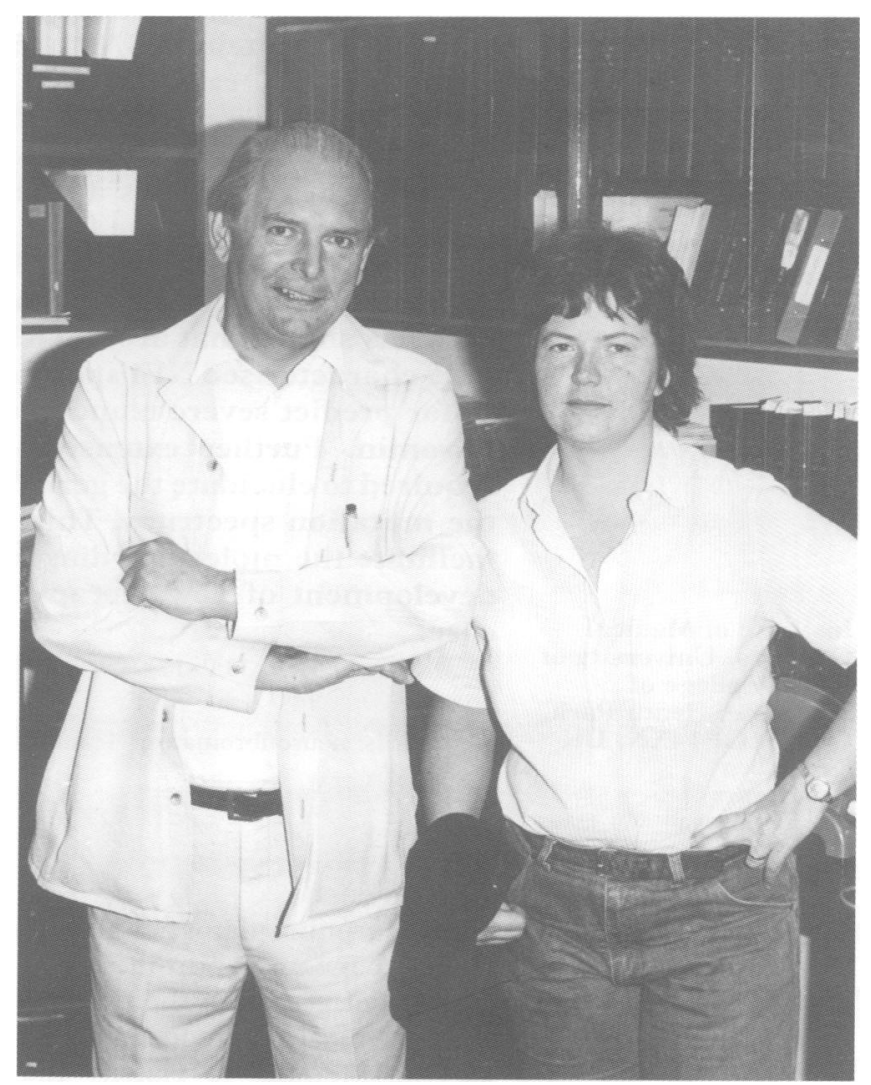

